\title{
Article
}

\section{Improvement of Temperature and Optical Power of an LED by Using Microfluidic Circulating System of Graphene Solution}

\author{
Yung-Chiang Chung *, Han-Hsuan Chung and Shih-Hao Lin \\ Department of Mechanical Engineering, Ming Chi University of Technology, New Taipei 24301, Taiwan; \\ gary850311@gmail.com (H.-H.C.); M07118021@mail2.mcut.edu.tw (S.-H.L.) \\ * Correspondence: ycchung@mail.mcut.edu.tw
}

check for updates

Citation: Chung, Y.-C.; Chung, H.-H.; Lin, S.-H. Improvement of Temperature and Optical Power of an LED by Using Microfluidic

Circulating System of Graphene Solution. Nanomaterials 2021, 11, 1719. https://doi.org/10.3390/

nano11071719

Academic Editors: Eugene Kogan and Filippo Giannazzo

Received: 29 April 2021

Accepted: 26 June 2021

Published: 29 June 2021

Publisher's Note: MDPI stays neutral with regard to jurisdictional claims in published maps and institutional affiliations.

Copyright: (C) 2021 by the authors. Licensee MDPI, Basel, Switzerland. This article is an open access article distributed under the terms and conditions of the Creative Commons Attribution (CC BY) license (https:/ / creativecommons.org/licenses/by/ $4.0 /)$.

\begin{abstract}
Electric devices have evolved to become smaller, more multifunctional, and increasingly integrated. When the total volume of a device is reduced, insufficient heat dissipation may result in device failure. A microfluidic channel with a graphene solution may replace solid conductors for simultaneously supplying energy and dissipating heat in a light emitting diode (LED). In this study, an automated recycling system using a graphene solution was designed that reduces the necessity of manual operation. The optical power and temperature of an LED using this system was measured for an extended period and compared with the performance of a solid conductor. The temperature difference of the LED bottom using the solid and liquid conductors reached $25^{\circ} \mathrm{C}$. The optical power of the LED using the liquid conductor was higher than that of the solid conductor after 120 min of LED operation. When the flow rate was increased, the temperature difference of the LED bottom between initial and $480 \mathrm{~min}$ was lower, and the optical power of the LED was higher. This result was attributable to the higher temperature of the LED with the solid conductor. Moreover, the optical/electric power transfer rate of the liquid conductor was higher than that of the solid conductor after $120 \mathrm{~min}$ of LED operation, and the difference increased over time.
\end{abstract}

Keywords: liquid conductor; graphene solution; circulating system; microfluidic channel; temperature; optical power

\section{Introduction}

Heat dissipation and electrical conduction are critical considerations in the operation of an integrated circuit device. Solid metal conductors are typically used for conducting electricity. Several heat dissipation methods, such as the use of microfluidic devices, are employed in electric systems. For example, researchers have considered using nanofluids for cooling electric devices [1,2]. Studies have proposed a thermal contact liquid cooling system [3] as well as a technique for cooling photovoltaic cell systems through the use of rotating magnetic fields and ferrofluids [4]. A related study used a system combining liquid cooling and composite phase change material cooling to dissipate the heat generated in a battery [5]. Liquid cooling systems have also been applied in central processing units and laptops [6,7]. Research has revealed various cooling methods for electric devices [8-10]. Some studies have also employed the recycling of various fluids, such as ammonia [11], $\mathrm{CO}_{2}$ [12], and supercritical water [13] for cooling. Additionally, researchers have introduced a one-section and two-stepwise microchannel for cooling [14] and a recirculating cooling water system to reduce energy consumption [15]. Another study considered the cooling effect of dielectric liquid [16], and yet another reported that a fracture in the neck of the bond between the solder joint and gold wire after 20 thermal shocks would result in metal conductors failing at high temperatures [17].

The dissipation of heat in light emitting diodes (LEDs) has been studied extensively. For example, researchers have investigated the temperature distribution [18] and liquid cooling systems $[19,20]$ of an LED array. Furthermore, composite coatings composed of cupric oxide [21] or various heat pipes and heat sinks [22-28] have been employed to 
enhance the heat dissipation of LEDs. Other relevant studies have used a dielectric layer with an aluminum nitride insulation plate [29] and a dual synthetic jet actuator for heat dissipation in LEDs [30]. A cooling system with ferrofluid was used in a high-power LED; the results were compared with those of systems employing air and water working fluid, and the effect of ferrofluid was the best [31]. A thermoelectric cooler integrated with a microchannel heat sink was used to control LED temperature [32]. Another study proposed the energy recycling and self-sufficient application of an LED integrated with a thermoelectric generator module and electrical fan [33]. Moreover, graphene has been employed as a novel material in several investigations [34,35]. Some researchers have considered the thermophysical properties and forced convective heat transfer performance of graphene [36,37] and reviewed the applications of graphene [38,39]. Researchers have suggested that the conductivity of water can be improved through the addition of mono and hybrid nano-additives containing graphene and silica [40] and have developed a method that integrates graphene nanocapillaries into a micro heat pipe for enhanced LED cooling [41]. Graphene solutions have been widely applied to increase heat transfer efficiency [42-47], and a higher graphene solution concentration has been demonstrated to result in greater heat transfer [48,49]. Moreover, some researchers have studied thermal conductivity and electrical conductivity of graphene nanoplatelets [50,51]. The aforementioned investigations have concentrated on either dissipating heat or supplying energy but have not considered the combination of energy supply and heat dissipation. Furthermore, numerous studies have examined the energy conversion of artificial light [52-55] and white light LEDs [56-58]. Evidence suggests that the power conversion efficiencies of solar cells and LEDs are lower than $53.6 \%[59,60]$ and that the efficiency of LEDs is $42 \%$ at $30{ }^{\circ} \mathrm{C}$, dropping to $30 \%$ at $50{ }^{\circ} \mathrm{C}$ [61]. However, the aforementioned studies focused predominantly on energy conversion from optical power to electric power; energy conversion from electric power to optical power has seldom been discussed. The stability and reliability of an electric apparatus may decrease by $10 \%$ when the temperature is increased by $2{ }^{\circ} \mathrm{C}$ [62]. In another investigation, a graphene solution was used as a liquid conductor for dissipating heat and transferring energy; the heat dissipation efficiency was excellent, but the optical power of an LED with a liquid conductor was lower than that of an LED with a solid conductor during the first $6 \mathrm{~min}$, and the graphene solution was recycled manually [63]. According to the aforementioned study, the temperature of the LED using the liquid conductor was much lower than that of the LED using the solid conductor. However, the optical power of LEDs using liquid and solid conductors was not compared over longer periods. Therefore, to supply energy and dissipate heat of an LED during longer experiments, the graphene solution can be automatically recycled. Such a system can simultaneously dissipate heat and supply energy as well as improve the LED's optical power. The optical power of the LED using the liquid conductor may be higher than that of the LED using the solid conductor over longer periods. Therefore, in this study, an automated liquid conductor circulating system was developed and the energy supply and heat dissipation of an LED was studied over an extended period.

\section{Materials and Methods}

\subsection{Principle of Operation}

A liquid conductor that can dissipate heat and conduct electricity simultaneously may effectively reduce the temperature of electric products and enhance the photoelectricity transfer efficiency. Related research has indicated that the temperature of an LED using a liquid conductor is much lower than that of an LED using a solid conductor. Thus, the effect of the temperature of the LED on its optical power, especially during extended periods, merits further study.

\subsection{Chip Design and Fabrication}

Microfluidic channels were fabricated using a microelectromechanical process, as displayed in Figure 1a,b. The widths of the inlet and outlet of the channel were $0.5 \mathrm{~mm}$, 
and the length of the channel was $20 \mathrm{~mm}$; the distance between the channels was 0.5 and $1 \mathrm{~mm}$, respectively. As displayed in Figure 2a, first, the wafer was cleaned using acetone and deionized water. Second, the periphery of wafer was coated with Teflon and baked; the periphery of the wafer was hydrophobic to enhance the photoresist coating. The silicon wafer was coated with SU8 photoresist with a thickness of approximately $500 \mu \mathrm{m}$ at $200 \mathrm{rpm}$. Subsequently, the wafer was soft baked and the solvent in the photoresist was removed. The wafer was exposed to define the pattern, and it was baked after exposure to enhance the linking process of the photoresist. After the wafer was developed, the developer removed the undefined region. Subsequently, the polydimethylsiloxane (PDMS) substrate microfluidic channel chip was fabricated. As illustrated in Figure $2 b$, the Teflon was coated on the wafer and the PDMS was poured into the wafer; the wafer was hydrophobic to facilitate the fabrication of the PDMS substrate. The wafer was then vacuumed to remove the bubbles in the PDMS, and the wafer was heated to solidify the PDMS. Once the wafer had cooled, the PDMS could be separated from the wafer, and the PDMS substrate microfluidic channel chip was complete.

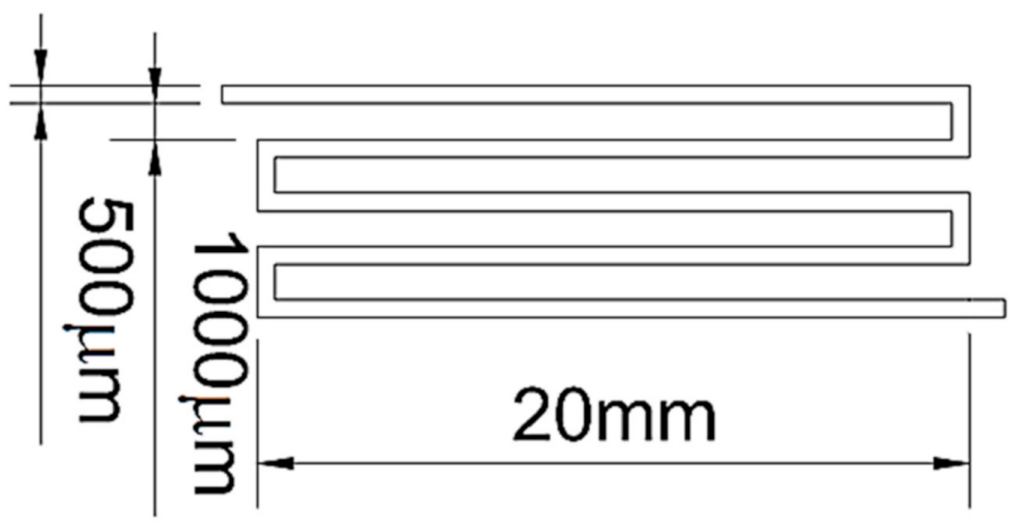

(a)

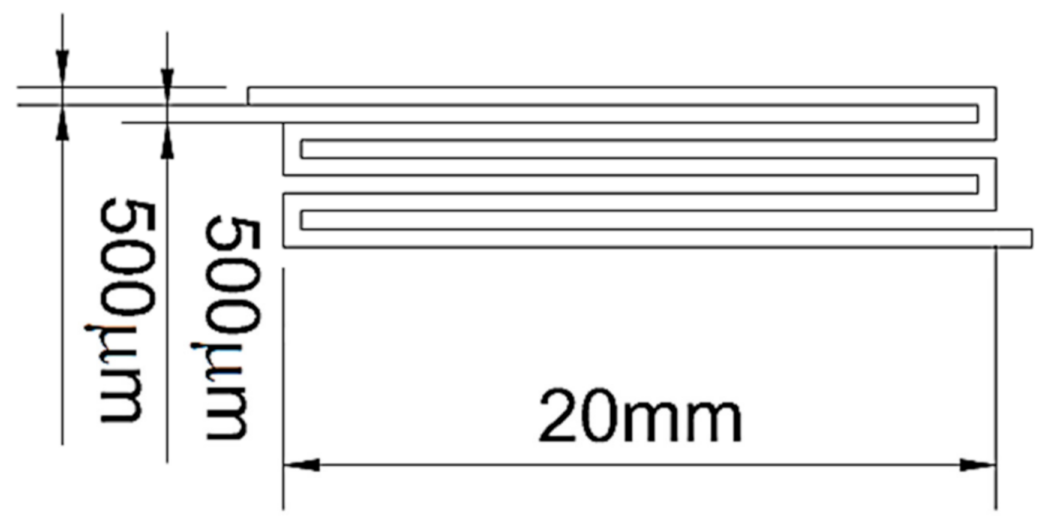

(b)

Figure 1. Schematics of the LED chip with a microfluidic channel: (a) distance between the channel $d=1 \mathrm{~mm}$; (b) distance between the channel $d=0.5 \mathrm{~mm}$. 


\section{Cleaning}

\section{Teflon coating}

\section{Photoresist coating}

4.Soft bake

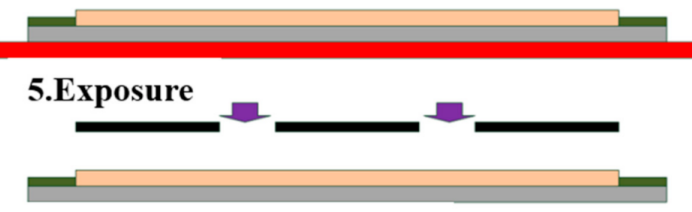

6.Bake after exposure



7.Development



(a)

\section{Teflon coating}

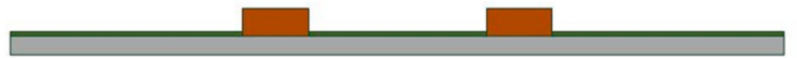

\section{PDMS pouring}

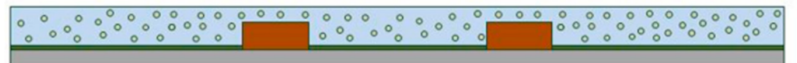

3.Vacuuming



\section{Solidifying}

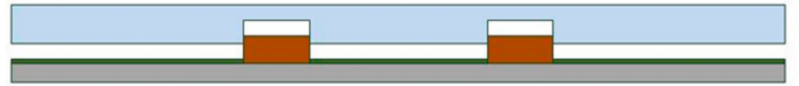

Si Wafer $\square$ PDMS $\bigcirc$ Air

Teflon $\square$ SU8-Structure

(b)

Figure 2. Fabrication of the microfluidic channels: (a) SU8 mold chip; (b) PDMS substrate microfluidic channel chip. 
The designated area for a microscope slide $\left(75 \times 25 \times 1 \mathrm{~mm}^{3}\right)$ was coated with silver adhesive (OP-901, Double O Technology, Taiwan), as shown in Figure 3a, which was connected to the microfluidic channel and the LED. The PDMS substrate microfluidic channel chip and the microscope slide coated with silver adhesive were bonded together to form the chip. The LED (emission color: white; TY-HNW2-3, TaoYuan Electron Limited, Taiwan) was placed at the center of the chip. The silver adhesive was coated on the electrodes of the LED, connecting it with the silver adhesive of the chip. The size of the liquid recycling reservoir was $75 \times 25 \times 13 \mathrm{~mm}^{3}$. The area between the needle and the microfluidic channel was sealed with ultraviolet glue to ensure that the liquid would not leak. Finally, the chip, the liquid or solid conductor, the liquid recycling reservoir, and the LED were integrated to form an LED with a liquid circulating system, shown in Figure 3b.

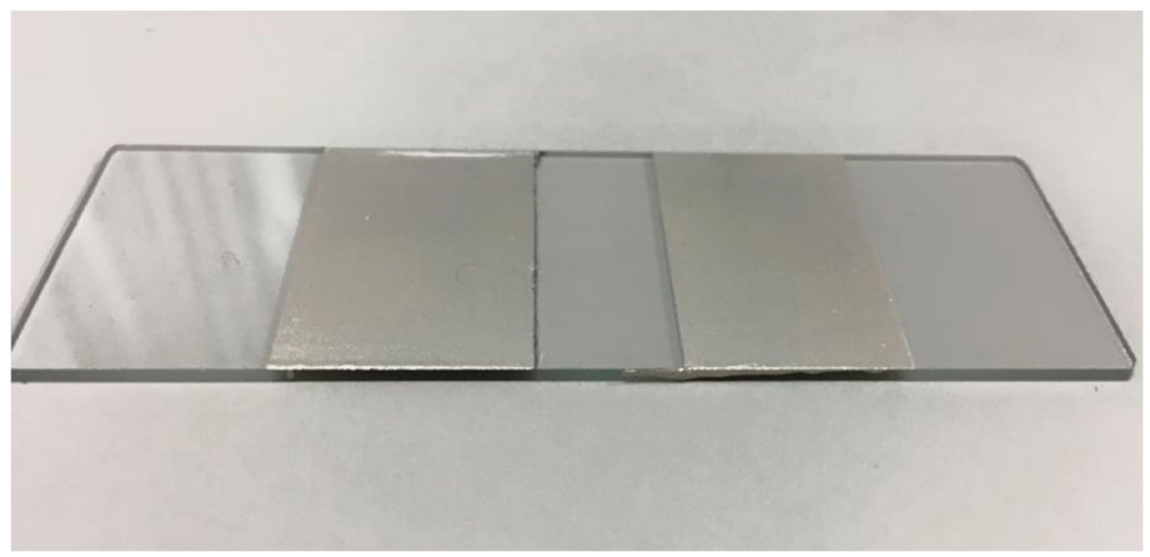

(a)

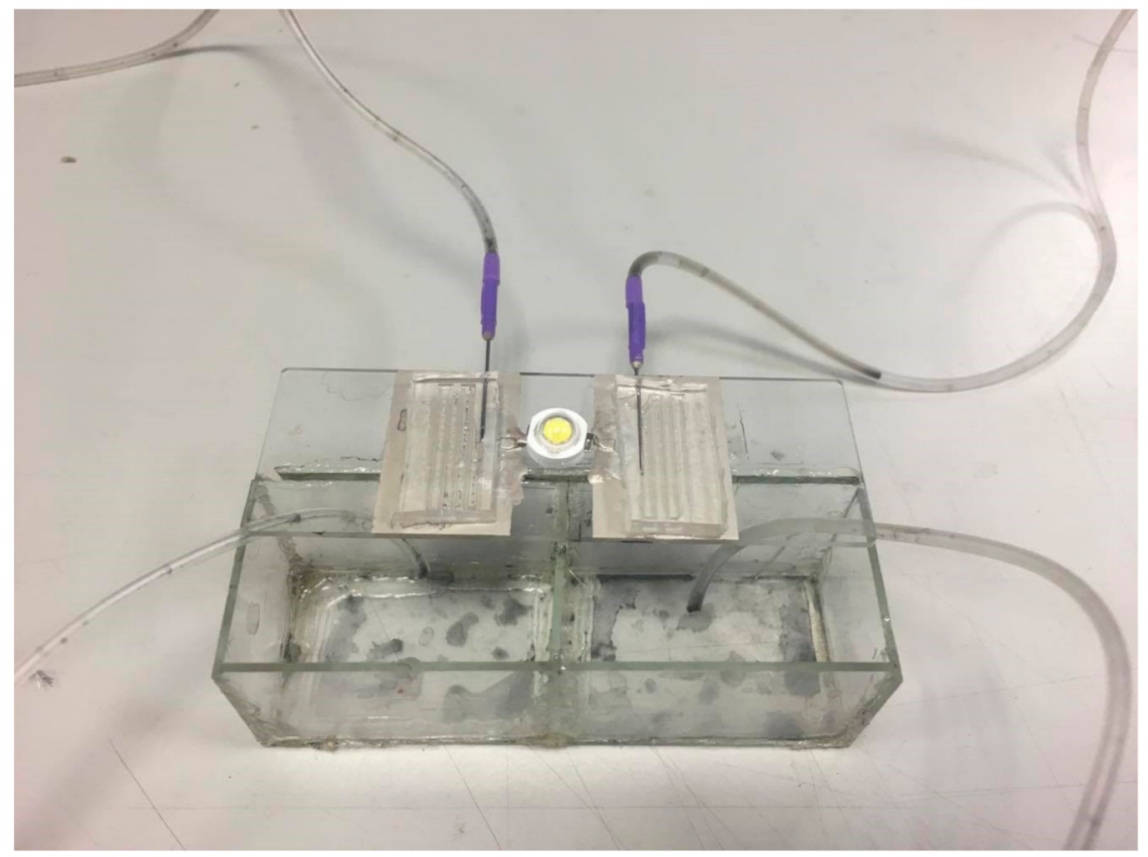

(b)

Figure 3. Schematics of the system: (a) image of the microscope slide with silver adhesive; (b) image of the LED with a liquid circulating system.

\subsection{Sample Preparation and Experimental Setup}

A graphene solution (Golden Innovation Business Co., Ltd., New Taipei, Taiwan) was used as the liquid conductor in this study. The size of the graphene particles in the solution was $100 \mathrm{~nm}$, the solution was deionized water, and the concentration was $500 \mathrm{ppm}$. The needle was placed into the microfluidic channel. The graphene solution was fully mixed 
using an acoustic vibrator, and the solution was injected into the needle and microfluidic channel. The flow rate was regulated using a piezoelectric micropump (CurieJet, PS51I, Microjet Technology, Hsinchu, Taiwan); the flow rate ranged from 0.01 to $10 \mathrm{~mL} / \mathrm{min}$. A solid conducting nickel-plated steel wire (diameter: $1 \mathrm{~mm}$ ) was used as the solid conductor. The power supply system (LPS305, Motech, Tainan, Taiwan) could produce an output voltage of $\pm 30 \mathrm{~V}$. The LED system included the power supply, a syringe pump, the chip, and the graphene solution (or solid conductor). The temperature was measured using resistance temperature detectors (RTDs; PT 100 series, OMEGA Engineering Inc., Norwalk, Connecticut, USA), and the optical power of the LED was measured using an optical power meter (Gentec Electro-Optique Inc., Quebec, Quebec, Canada). The integrated system (Figure 4) included the LED system, power supply, syringe pump, temperature data receiver, and optical power sensor. In this study, the temperature and optical power of the LED were measured over an extended period, and the effect of the temperature on the optical power was examined.



Figure 4. Schematic of the integrated system.

\section{Results and Discussion}

In this study, liquid (graphene solution) and solid (nickel-plated steel wire with a diameter of $1 \mathrm{~mm}$, length of $30 \mathrm{~mm}$ ) conductors were used. The temperatures at the bottom of the LED chip and the microfluidic channel were measured. Moreover, the optical power of the LED under various conditions was measured at a distance of $3 \mathrm{~mm}$ from the LED. The uncertainty analysis results of various parameters are listed in Table 1. Experiments were performed five times under each set of experimental conditions, and the average error was less than $20 \%$. The temperatures at the center and four corners were measured, and the temperature variation was lower than $2{ }^{\circ} \mathrm{C}$. Because the temperature at the center of 
the chip bottom was the highest, it was selected to represent the temperature of the LED chip (Figure 5).

Table 1. Uncertainty analysis of various parameters.

\begin{tabular}{ccc}
\hline Parameter & Instrument & Uncertainty \\
\hline Electric resistance and voltage & Digital multimeters & $0.1 \%$ \\
Flow rate & Piezoelectric pump & $0.5 \%$ \\
Temperature & Resistance temperature detectors & $0.1^{\circ} \mathrm{C}$ \\
Optical power & Optical power meter & $0.5 \%$ \\
\hline
\end{tabular}



Glass Structure $\square$ Sliver Glue $\square$ PDMS
Micro-Channel
LED
Measure Point

Figure 5. Schematic of the temperature measurement points of the LED bottom and microfluidic channel.

\subsection{Energy Supply}

The actual voltage of the LED with the graphene solution conductor differed from the voltage of the power supply. The actual voltages of the LED with the graphene solution were measured at various power supply voltages (Figure 6). The results indicated that the voltage of the graphene solution-conductor LED was $2.8 \mathrm{~V}$ when the voltage of the power supply was $5.5 \mathrm{~V}$. The highest operational voltage of the LED was $3 \mathrm{~V}$. Therefore, the actual voltage of the LED with the solid and liquid conductors was selected as $2.8 \mathrm{~V}$ in this study. 




Figure 6. Electric voltages of the LED with the liquid conductor at various power supply electric voltages.

\subsection{Temperature Variation Using Different Conductors}

The measured temperatures of the LEDs with solid and liquid conductors are listed in Figure 7. The temperatures of the LED bottom and the microfluidic channel bottom increased over time. For the solid conductor, the temperatures of the LED bottom increased to $58^{\circ} \mathrm{C}$ at $50 \mathrm{~min}$, and the temperatures increased gradually to $65.5^{\circ} \mathrm{C}$ at $480 \mathrm{~min}$. The temperatures of the microfluidic channel bottom increased to $51.5^{\circ} \mathrm{C}$ at $50 \mathrm{~min}$ and continued to increase gradually to $59.4^{\circ} \mathrm{C}$ at $480 \mathrm{~min}$. The temperature difference between the LED bottom and the microfluidic channel bottom was $6-7^{\circ} \mathrm{C}$. The measured temperatures of the liquid conductors $(d=500$ and $1000 \mu \mathrm{m})$ also increased over time. When $d=1 \mathrm{~mm}$, the temperatures of the LED bottom and the microfluidic channel bottom increased over time. The temperatures of the LED bottom increased to $37.2^{\circ} \mathrm{C}$ at $50 \mathrm{~min}$ and continued to increase gradually to $41^{\circ} \mathrm{C}$ at $480 \mathrm{~min}$. The temperatures of the microfluidic channel bottom increased to $28.2^{\circ} \mathrm{C}$ at $50 \mathrm{~min}$ and continued to increase gradually to $30.5^{\circ} \mathrm{C}$ at $480 \mathrm{~min}$. The temperature difference between the LED bottom and the microfluidic channel bottom was $9-10.5{ }^{\circ} \mathrm{C}$. When $d=0.5 \mathrm{~mm}$, the temperatures of the LED bottom increased to $36.2^{\circ} \mathrm{C}$ at $50 \mathrm{~min}$ and increased gradually to $40^{\circ} \mathrm{C}$ at $480 \mathrm{~min}$. The temperatures of the microfluidic channel bottom increased to $28^{\circ} \mathrm{C}$ at $50 \mathrm{~min}$ and increased gradually to $30^{\circ} \mathrm{C}$ at $480 \mathrm{~min}$. The temperature difference between the LED bottom and the microfluidic channel bottom was $8.2-10{ }^{\circ} \mathrm{C}$. The temperatures of the LED bottom and microfluidic channel bottom were lowest in the liquid conductor with $d=0.5 \mathrm{~mm}$, but the temperature differences between these two parts did not differ considerably between the liquid conductors with $d=0.5$ and $1 \mathrm{~mm}$. Furthermore, the temperature difference of the LED bottom between the solid conductor and the liquid conductor reached $25^{\circ} \mathrm{C}$. This result emphasizes the temperature reduction effect of the LED using the liquid conductor. 


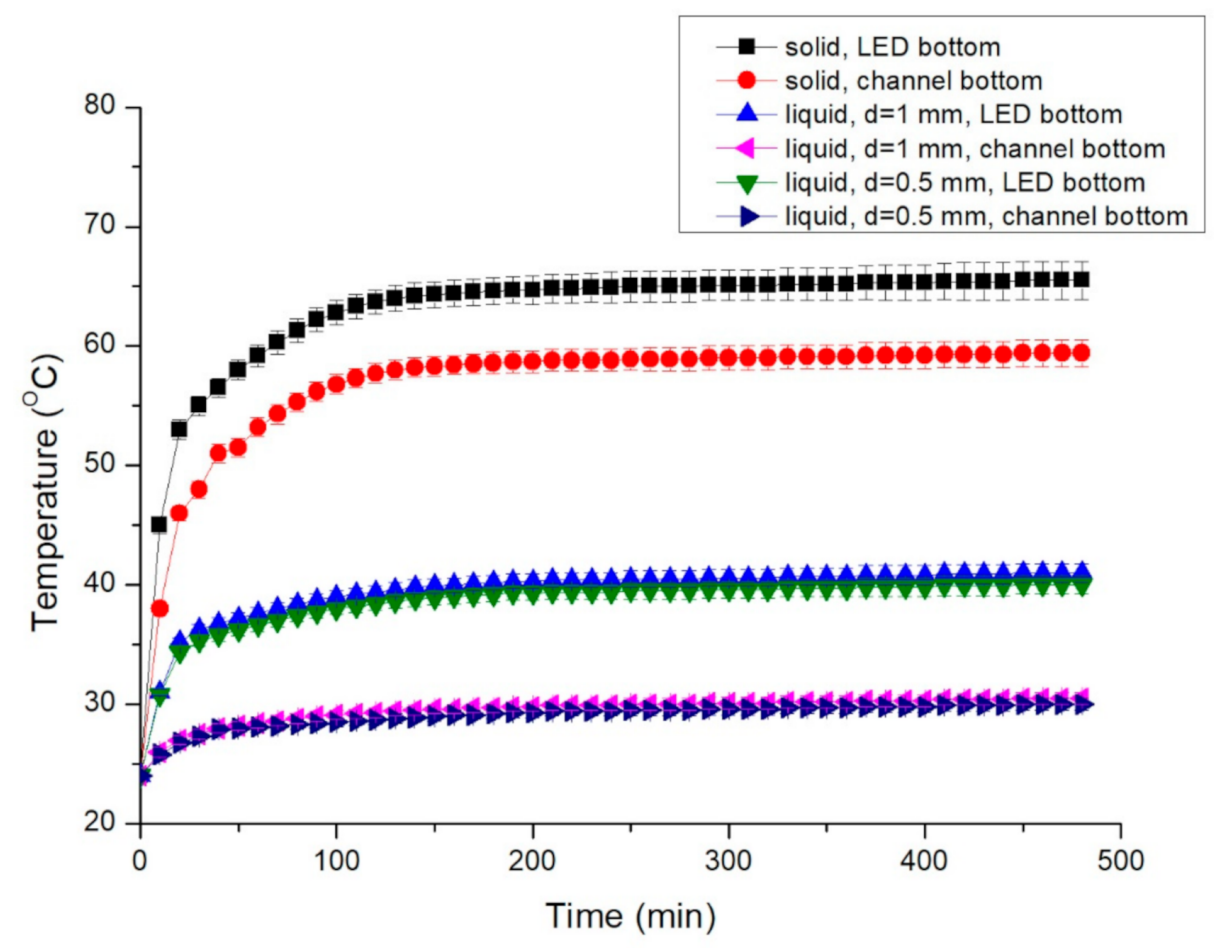

Figure 7. Temperatures of the bottom of the LED bottom and channel bottom with various conductors.

The temperature differences of the LED bottom between initial and $480 \mathrm{~min}$ using solid conductor and graphene solution with various flow rates are shown in Figure 8 . The temperature difference using the solid conductor was $35.1^{\circ} \mathrm{C}$. The temperature differences using the graphene solution were $17.2,13.4,11.5$ and $10.1^{\circ} \mathrm{C}$ at flow rates of $0,0.05,0.2$ and $1 \mathrm{~mL} / \mathrm{min}$, respectively. When the flow rate was increased, the temperature difference was lower and the heat dissipation of the graphene solution was excellent. The heat dissipation of the graphene solution was apparently higher than that of the solid conductor. At static state, the heat dissipation of the graphene solution was still higher than that of the solid conductor.

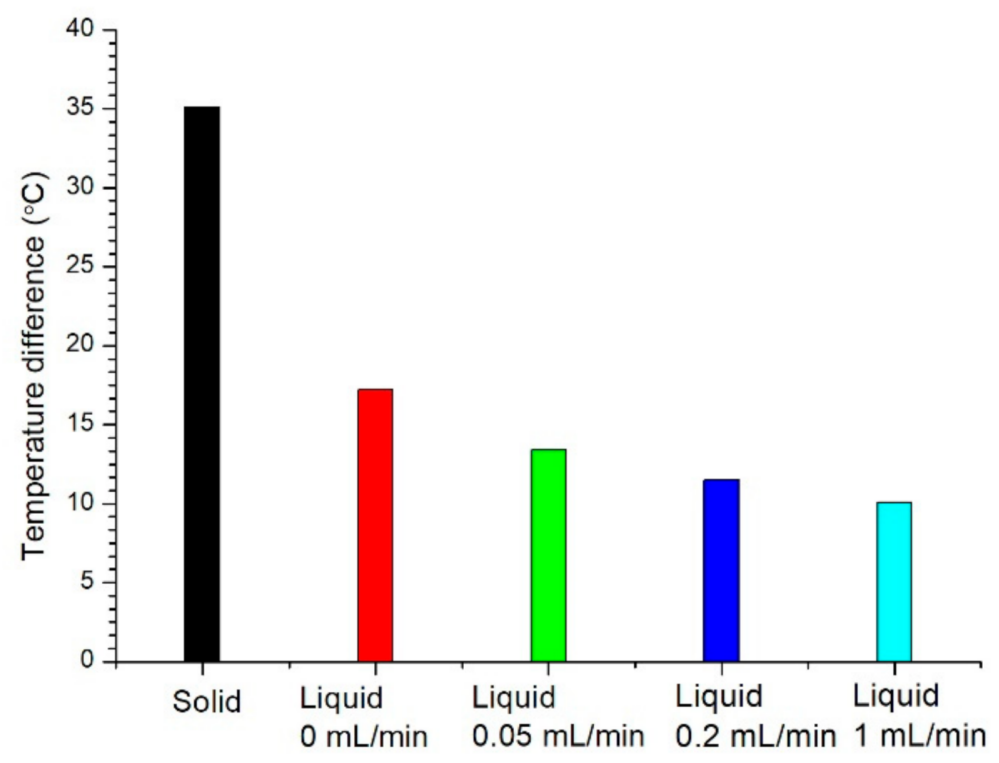

Figure 8. Temperature differences of the LED bottom between initial and $480 \mathrm{~min}$ using solid conductor and graphene solution with various flow rates. 
The temperature decreases of the LED using various cooling methods are shown in Figure 9. The temperature decrease in the LED with fin only was $3^{\circ} \mathrm{C}$, that of the LED with fan only was $8{ }^{\circ} \mathrm{C}$, and that of the LED with fin and fan could be $10{ }^{\circ} \mathrm{C}[22,23]$. The temperature decrease in the LED with heat pipe was larger than $7^{\circ} \mathrm{C}$ [24-27], that of the LED with dielectric layer could reach $20^{\circ} \mathrm{C}$ [29], and it may be larger than $25^{\circ} \mathrm{C}$ using a ferrofluid [31]. In this study, the temperature decrease in the LED reached $30{ }^{\circ} \mathrm{C}$ using a graphene solution. The temperature decrease in the LED in this study was equal to or larger than that using other cooling methods.



Figure 9. Temperature differences of LED using various cooling methods.

The thermal conductivity $k_{s}$ of the solid conductor was about $15 \mathrm{~W} / \mathrm{m} \cdot{ }^{\circ} \mathrm{C}$. The thermal conductivity of graphene was about $5300 \mathrm{~W} / \mathrm{m} \cdot{ }^{\circ} \mathrm{C}$. The thermal conductivity of the graphene solution $k_{\mathrm{g}}$ was about $20-100 \mathrm{~W} / \mathrm{m} \cdot{ }^{\circ} \mathrm{C}$ for various concentration for 200-1000 ppm (from graphene solution company, Golden Innovation Business Co., Ltd., New Taipei, Taiwan.).

The thermal resistance of a solid conductor can be expressed as follows $[64,65]$ :

$$
R_{\mathrm{th}, \mathrm{s}}=1 /\left(k_{\mathrm{s}} \mathrm{A} / \Delta x\right)
$$

where $\Delta x$ is the distance between two locations, and $\mathrm{A}$ is the area between two locations. Consider the convection heat transfer coefficient $h$, the thermal resistance of a graphene solution can be expressed as follows:

$$
R_{\mathrm{th}, \mathrm{g}}=1 /\left(k_{g} \mathrm{~A} / \Delta x+h \mathrm{~A}\right)
$$

The value $h$ of water was $1000-35000 \mathrm{~W} / \mathrm{m}^{2} \cdot{ }^{\circ} \mathrm{C}$ for various flow rates $[64,65]$.

Based on the comparison between $R_{\mathrm{th}, \mathrm{s}}$ and $R_{\mathrm{th}, \mathrm{g}}$, the thermal resistance of the graphene solution with flow rate was smaller than that of the solid conductor, and the heat transfer of the LED was improved.

\subsection{Optical Power Variation Using Different Conductors}

The optical power at various distances between the LED and the power meter is displayed in Figure 10. The optical power of the LED did not decrease noticeably when the 
distance was lower than $5 \mathrm{~mm}$. However, it decreased markedly when the distance was greater than $10 \mathrm{~mm}$. The optical power at a distance of $3 \mathrm{~mm}$ from the LED was selected as the representative value. The optical power of the LEDs measured using solid and liquid conductors is displayed in Figure 11. The maximum optical power of the LED with the solid conductor was $30.5 \mathrm{~mW}$ at $10 \mathrm{~min}$, and it decreased gradually. The optical power decreased noticeably after $120 \mathrm{~min}$, and that of the LED with the liquid conductor with $d=0.5 \mathrm{~mm}$ increased gradually before $30 \mathrm{~min}$ and stabilized at $29 \mathrm{~mW}$ by $200 \mathrm{~min}$. The optical power of the LED with the liquid conductor with $d=1 \mathrm{~mm}$ increased gradually before $30 \mathrm{~min}$ and stabilized at $28.8 \mathrm{~mW}$ by $180 \mathrm{~min}$. The optical power of the LED with the solid conductor was greater than that of the liquid conductor until $90 \mathrm{~min}$. The optical power difference of the LED with liquid conductors with various $d$ values was small. The temperature of the LED with the liquid conductor was much lower than that of the LED with the solid conductor after $30 \mathrm{~min}$ (Figure 7). The temperature differences between the LED bottoms with the liquid and solid conductors increased over time during the first $120 \mathrm{~min}$ and then stabilized at approximately $24^{\circ} \mathrm{C}$. The optical power of the LED with the liquid conductor was higher than that of the solid conductor after $120 \mathrm{~min}$, and the optical power difference was approximately $3 \mathrm{~mW}$ after $150 \mathrm{~min}$. This result was attributable to the higher temperature of the LED with the solid conductor.

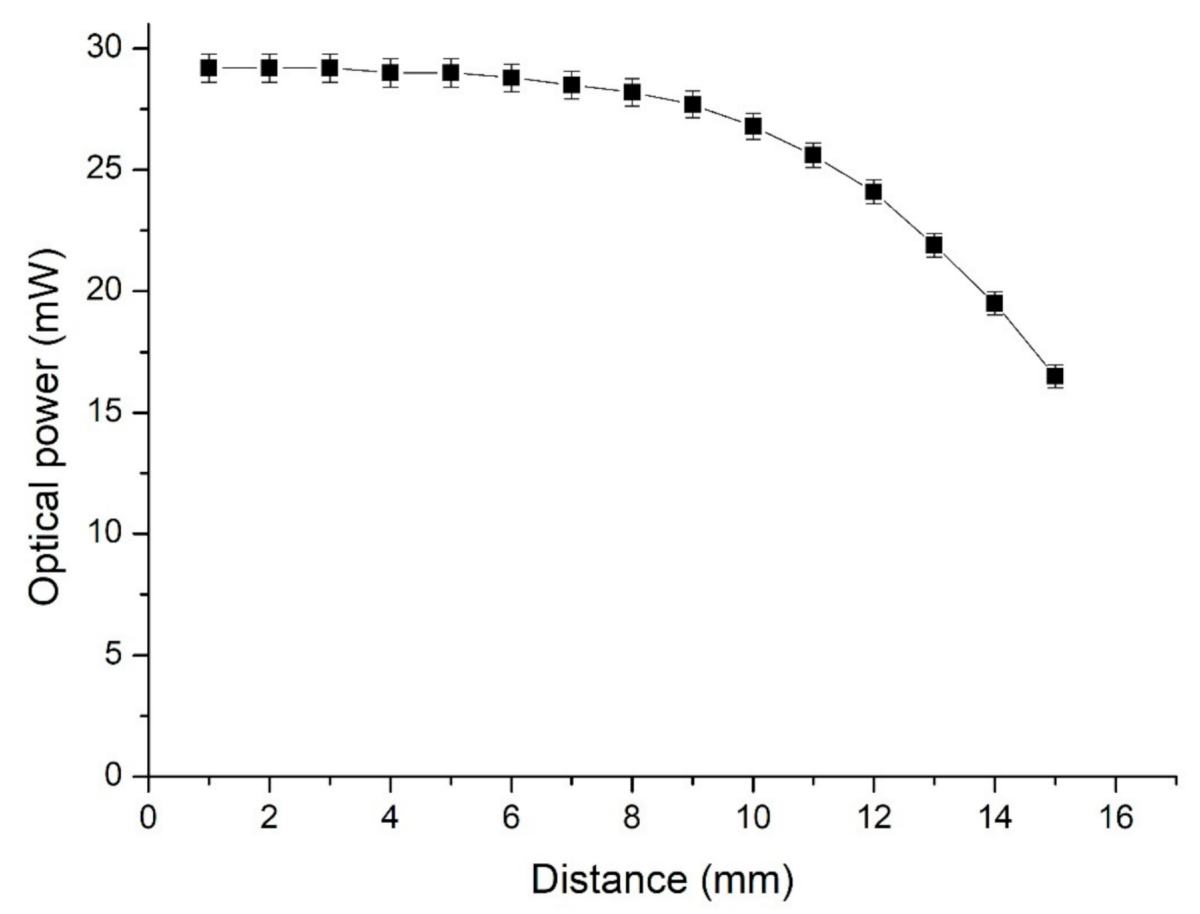

Figure 10. Optical power of the LED chip at various distances between the LED and the power meter. 


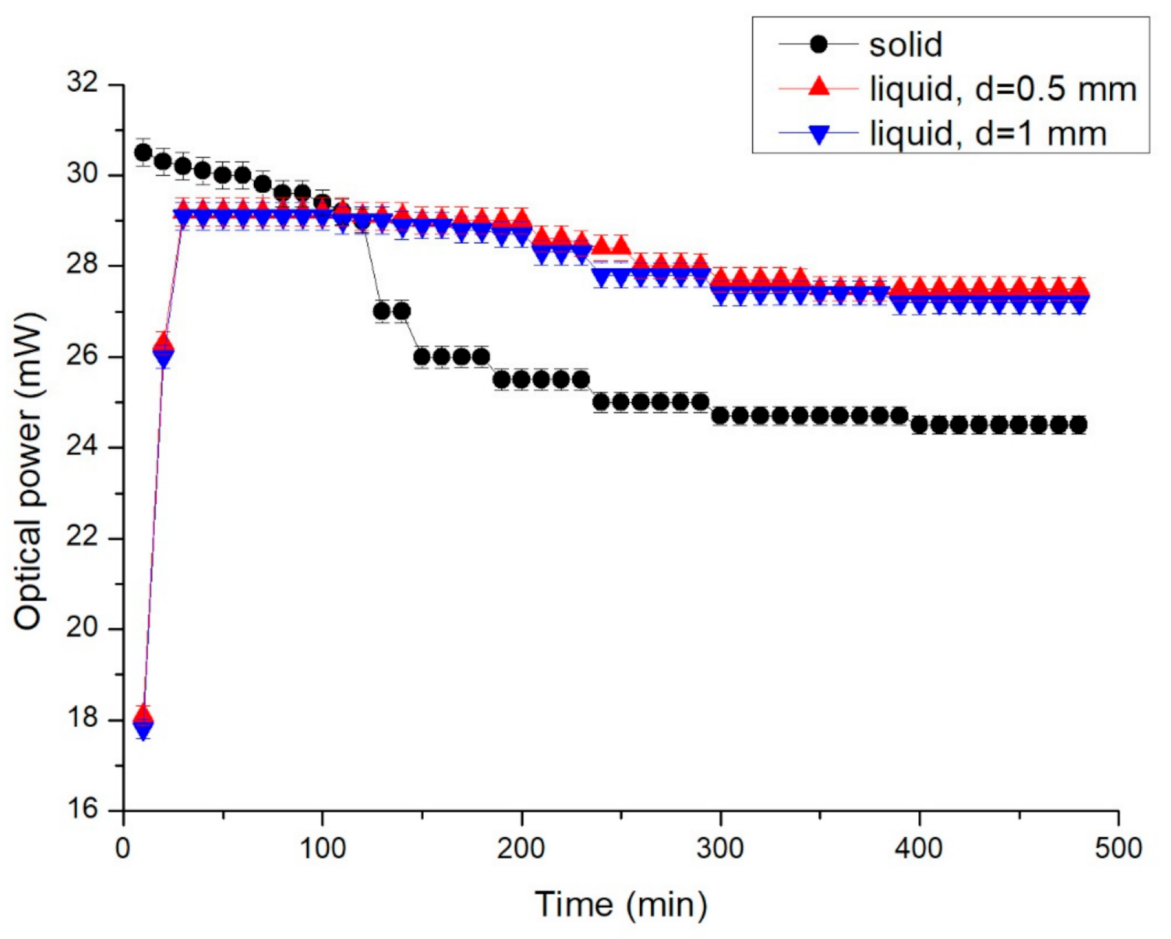

Figure 11. Optical power of the LED chip with various conductors and distances between channels.

\subsection{Comparison of Power Transfer}

The liquid pumping power (additional energy) required to pump the graphene solution is discussed in this section. The liquid pumping power, $P_{l}(\mathrm{~W})$ can be expressed as follows [44]:

$$
P_{l}=(\Delta P) \times Q
$$

where $\Delta P$ is the pressure drop $(\mathrm{kPa})$, and $Q$ is the flow rate $\left(\mathrm{m}^{3} / \mathrm{s}\right)$.

The maximum flow rate in this study was $1 \mathrm{~mL} / \mathrm{min}\left(1.67 \times 10^{-8} \mathrm{~m}^{3} / \mathrm{s}\right)$ and the pressure drop was approximately $50 \mathrm{kPa}$. The pumping power was estimated to be $8.3 \times 10^{-4} \mathrm{~mW}$. Compared with the optical power of the LED $(29 \mathrm{~mW})$, the pumping power was much lower. The overall operational expenditure of the device was unaffected in this study. Moreover, the volume of the graphene solution in the recycling system was $30 \mathrm{~mL}$ and the cost of the graphene solution was approximately USD 60. Thus, the cost of the graphene solution was not high, and the graphene solution could be automatically recycled. The cost of the graphene solution did not increase noticeably because it required no replenishment in this study. Such a system is highly convenient and avoids substantial increases in the total device cost. Therefore, a graphene-solution microfluidic channel is a favorable conductor for use in LEDs.

The optical power of the LED using the solid conductor and graphene solution with various flow rates at $480 \mathrm{~min}$ are shown in Figure 12. The optical power of the LED using the solid conductor was $24.5 \mathrm{~mW}$. The optical power of the LED using the graphene solution were $25.1,27.5,28.2$ and $28.8 \mathrm{~mW}$ at flow rates of $0,0.05,0.2$ and $1 \mathrm{~mL} / \mathrm{min}$, respectively. The optical power of the LED using the graphene solution was higher than that of the solid conductor. When the flow rate was increased, the optical power of the LED was higher, but the difference was not large. 


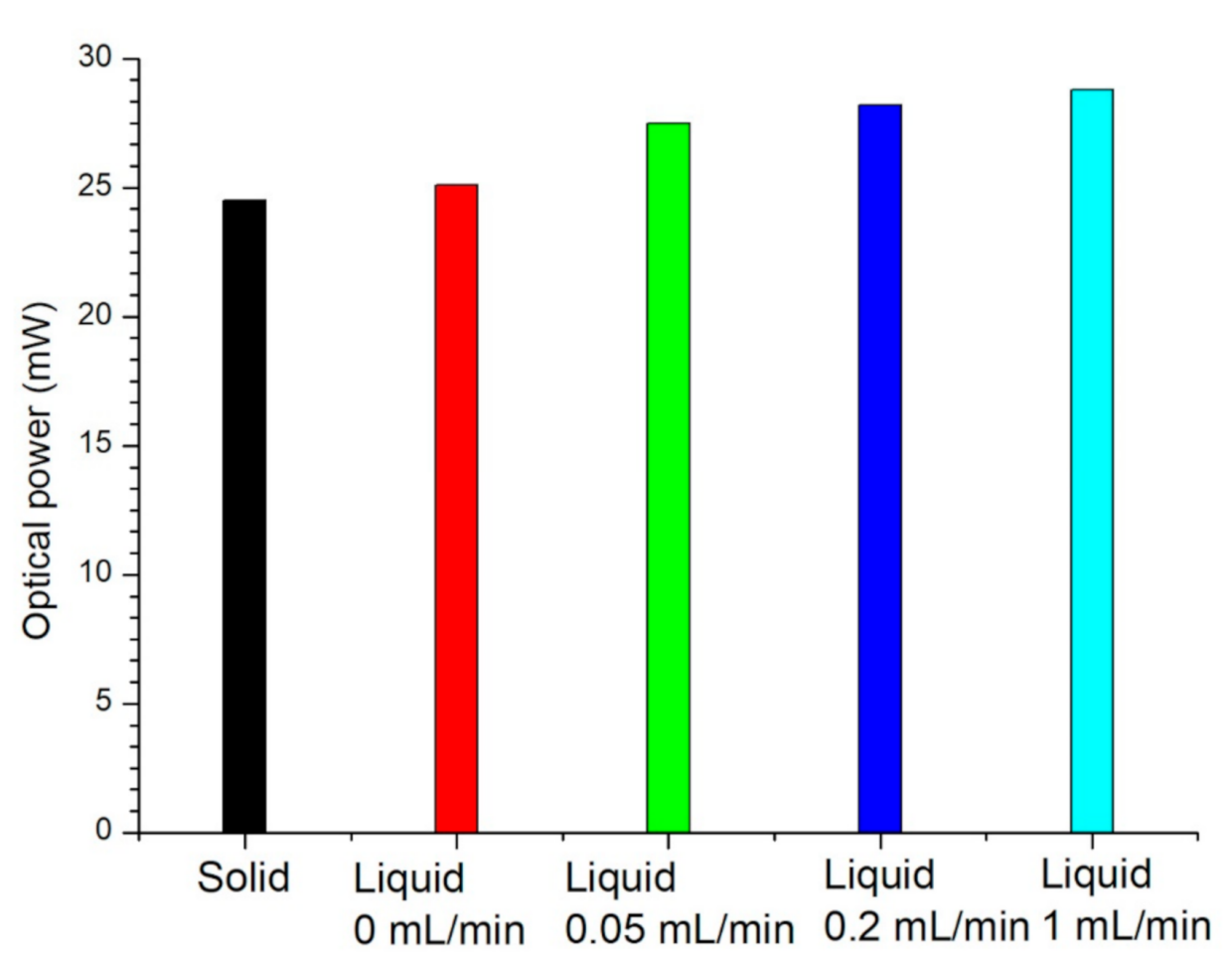

Figure 12. Optical power of the LED at $480 \mathrm{~min}$ using solid conductor and graphene solution with various flow rates.

The optical/electric power transfer rate of the LED was also investigated. The electric currents of the LED using various conductors were measured at 10, 40, 90, 150, and $480 \mathrm{~min}$ of LED operation. The supplied electric power was calculated using the following equation:

$$
P e=I \times V
$$

where $P e$ is the supplied electric power $(\mathrm{mW}), I$ is the electric current $(\mathrm{mA})$, and $V$ is the voltage $(\mathrm{V})$. The relative optical/electric power transfer rate was calculated using the following equation:

$$
R t=P o / P e
$$

where $R t$ is the optical/electric power transfer rate, Po is the measured optical power, and $\mathrm{Pe}$ is the supplied electric power. The results are presented in Figure 13. After $10 \mathrm{~min}$ of LED operation, the optical/electric power transfer rates were 50.1\%, 35.3\%, and 34.7\% for the solid conductor, the liquid conductor with $d=0.5 \mathrm{~mm}$, and the liquid conductor with $d=1 \mathrm{~mm}$, respectively. At $60 \mathrm{~min}$, the transfer rates were $45.0 \%, 42.7 \%$, and 41.9\%, respectively. At $120 \mathrm{~min}$, the transfer rates were $40.7 \%, 46.1 \%$, and $44.8 \%$, respectively. The optical/electric power transfer rate of the liquid conductor was higher than that of the solid conductor after $120 \mathrm{~min}$ of LED operation. Therefore, the optical/electric power transfer rate was affected by the temperature of the LED and was improved by the graphene-solution liquid conductor. 


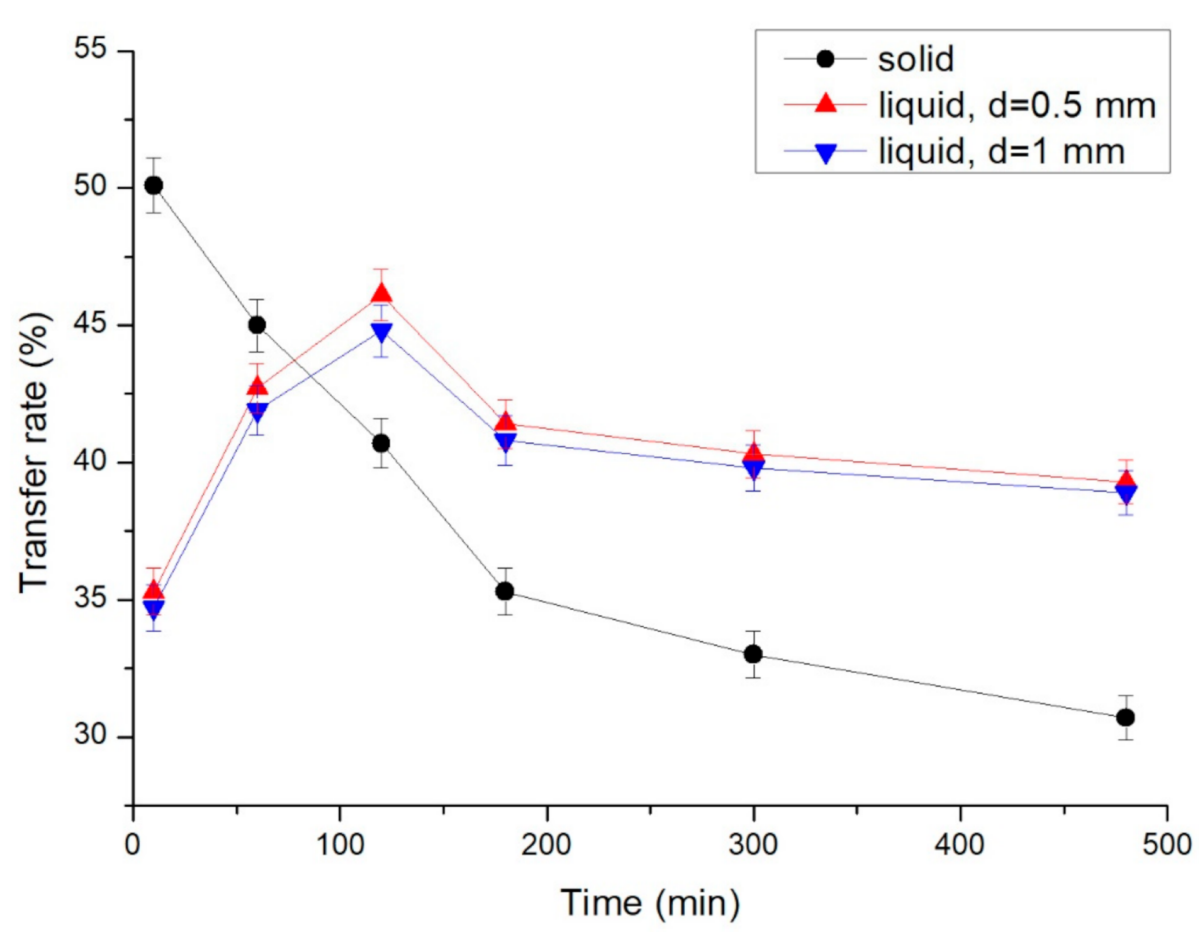

Figure 13. Optical/electric power transfer rate of the LED chip with various conductors and distances between channels.

\section{Conclusions}

This study proposes an automated graphene-solution circulating system that can efficiently dissipate heat and conduct electricity. The temperature and optical power of an LED were measured over an extended period. The thermal resistance of graphene solution with flow rate was smaller than that of the solid conductor, and the heat transfer of the LED was improved. The difference in temperature of the LED bottom between the LEDs using liquid and solid conductors reached $25^{\circ} \mathrm{C}$. After $120 \mathrm{~min}$ of LED operation, the optical power of the LED with the liquid conductor was higher than that of the solid conductor. When the flow rate was increased, the temperature difference of the LED bottom between initial and $480 \mathrm{~min}$ was lower, and the optical power of the LED was higher. This result is attributable to the higher temperature of the LED with the solid conductor. Furthermore, after $120 \mathrm{~min}$ of LED operation, the optical/electric power transfer rate of the liquid conductor was higher than that of the solid conductor, and the difference between them increased over time. The graphene-solution automated circulating system is a suitable conductor for LEDs and is particularly useful for operation over long periods.

Author Contributions: Conceptualization, Y.-C.C.; methodology, Y.-C.C. and H.-H.C.; validation, H.-H.C. and S.-H.L.; formal analysis, Y.-C.C., H.-H.C. and S.-H.L.; investigation, H.-H.C. and S.-H.L.; resource, Y.-C.C. and S.-H.L.; data curation, Y.-C.C., H.-H.C. and S.-H.L.; writing-original draft preparation, Y.-C.C.; writing-review and editing, Y.-C.C.; supervision, Y.-C.C.; project administration, Y.-C.C.; funding acquisition, Y.-C.C. All authors have read and agreed to the published version of the manuscript.

Funding: This research received no external funding.

Data Availability Statement: Authors ensure that data shared are in accordance with consent provided by participants on the use of confidential data. The data presented in this study are available on request from the corresponding author. The data are not publicly available due to the consideration of commercialization.

Conflicts of Interest: The authors declare no conflict of interest. 


\section{References}

1. Colangelo, G.; Favale, E.; Milanese, M.; de Risi, A.; Laforgia, D. Cooling of electronic devices: Nanofluids contribution. Appl. Therm. Eng. 2017, 127, 421-435. [CrossRef]

2. Bahiraei, M.; Heshmatian, S. Electronics cooling with nanofluids: A critical review. Energy Convers. Manag. 2018, 172, 438-456. [CrossRef]

3. Kheirabadi, A.C.; Groulx, D. Experimental evaluation of a thermal contact liquid cooling system for server electronics. Appl. Therm. Eng. 2018, 129, 1010-1025. [CrossRef]

4. Heidari, N.; Rahimi, M.; Azimi, N. Experimental investigation on using ferrofluid and rotating magnetic field (RMF) for cooling enhancement in a photovoltaic cell. Int. Commun. Heat Mass Transf. 2018, 94, 32-38. [CrossRef]

5. Zheng, Y.; Shi, Y.; Huang, Y. Optimisation with adiabatic interlayers for liquid-dominated cooling system on fast charging battery packs. Appl. Therm. Eng. 2019, 147, 636-646. [CrossRef]

6. Naphon, P.; Wiriyasart, S. Liquid cooling in the mini-rectangular fin heat sink with and without thermoelectric for CPU. Int. Commun. Heat Mass Transf. 2009, 36, 166-171. [CrossRef]

7. Ma, H.-K.; Chen, B.-R.; Gao, J.-J.; Lin, C.-Y. Development of an OAPCP-micropump liquid cooling system in a laptop. Int. Commun. Heat Mass Transf. 2009, 36, 225-232. [CrossRef]

8. Siahkamari, L.; Rahimi, M.; Azimi, N.; Banibayat, M. Experimental investigation on using a novel phase change material (PCM) in micro structure photovoltaic cooling system. Int. Commun. Heat Mass Transf. 2019, 100, 60-66. [CrossRef]

9. Nasef, H.A.; Nada, S.A.; Hassan, H. Integrative passive and active cooling system using PCM and nanofluid for thermal reg-ulation of concentrated photovoltaic solar cells. Energy Convers. Manag. 2019, 109, 112065. [CrossRef]

10. Zhou, F.; Joshi, S.N.; Liu, Y.; DeDe, E.M. Near-junction cooling for next-generation power electronics. Int. Commun. Heat Mass Transf. 2019, 108, 104300. [CrossRef]

11. Lu, W.; Meng, Z.; Sun, Y.; Zhong, Q.; Zhu, H. Improved energy performance of ammonia recycling system using floating con-densing temperature control. Appl. Therm. Eng. 2016, 102, 1011-1018. [CrossRef]

12. Gong, M.-H.; Yi, Q.; Huang, Y.; Wu, G.-S.; Hao, Y.-H.; Feng, J.; Li, W.-Y. Coke oven gas to methanol process integrated with CO2 recycle for high energy efficiency, economic benefits and low emissions. Energy Convers. Manag. 2017, 133, 318-331. [CrossRef]

13. Jin, H.; Fan, C.; Guo, L.; Liu, S.; Cao, C.; Wang, R. Experimental study on hydrogen production by lignite gasification in supercritical water fluidized bed reactor using external recycle of liquid residual. Energy Convers. Manag. 2017, 145, 214-219. [CrossRef]

14. Abou-Ziyan, H.; Ibrahim, M.; Abdel-Hameed, H. Characteristics enhancement of one-section and two-stepwise microchannels for cooling high-concentration multi-junction photovoltaic cells. Energy Convers. Manag. 2020, 206, 112488. [CrossRef]

15. Ma, K.; Liu, M.; Zhang, J. A method for determining the optimum state of recirculating cooling water system and experimental investigation based on heat dissipation efficiency. Appl. Therm. Eng. 2020, 176, 115398. [CrossRef]

16. Chen, P.; Harmand, S.; Ouenzerfi, S. Immersion cooling effect of dielectric liquid and self-rewetting fluid on smooth and porous surface. Appl. Therm. Eng. 2020, 180, 115862. [CrossRef]

17. Yang, H.; Yang, B.; Li, J.; Yang, P. Failure analysis and reliability reinforcement on gold wire in high-power COB-LED under current and thermal shock combined loading. Appl. Therm. Eng. 2019, 150, 1046-1053. [CrossRef]

18. Yung, K.C.; Liem, H.; Choy, H.S. Heat transfer analysis of a high-brightness LED array on PCB under different displacement configurations. Int. Commun. Heat Mass Transf. 2014, 53, 79-86. [CrossRef]

19. Lai, Y.; Cordero, N.; Barthel, F.; Tebbe, F.; Kuhn, J.; Apfelbeck, R.; Würtenberger, D. Liquid cooling of bright LEDs for automotive applications. Appl. Therm. Eng. 2009, 29, 1239-1244. [CrossRef]

20. Ramos-Alvarado, B.; Feng, B.; Peterson, G.P. Comparison and optimization of single-phase liquid cooling system devices for the heat dissipation of high-power LED arrays. Appl. Therm. Eng. 2013, 59, 648-659. [CrossRef]

21. Kim, D.; Lee, J.; Kim, J.; Choi, C.-H.; Chung, W. Enhancement of heat dissipation of LED module with cupric-oxide composite coating on aluminum-alloy heat sink. Energy Convers. Manag. 2015, 106, 958-963. [CrossRef]

22. Jang, D.; Yook, S.J.; Lee, K.S. Optimum design of a radial heat sink with a fin-height profile for high-power LED lighting ap-plications. Appl. Energy 2014, 116, 260-268. [CrossRef]

23. Cheng, H.H.; Huang, D.-S.; Lin, M.-T. Heat dissipation design and analysis of high power LED array using the finite element method. Microelectron. Reliab. 2012, 52, 905-911. [CrossRef]

24. Xiao, C.; Liao, H.; Wang, Y.; Li, J.; Zhu, W. A novel automated heat-pipe cooling device for high-power LEDs. Appl. Therm. Eng. 2017, 111, 1320-1329. [CrossRef]

25. Wang, Y.; Cen, J.; Jiang, F.; Cao, W. Heat dissipation of high-power light emitting diode chip on board by a novel flat plate heat pipe. Appl. Therm. Eng. 2017, 123, 19-28. [CrossRef]

26. Wang, M.; Tao, H.; Sun, Z.; Zhang, C. The development and performance of the high-power LED radiator. Int. J. Therm. Sci. 2017, 113, 65-72. [CrossRef]

27. Huang, D.-S.; Chen, T.-C.; Tsai, L.-T.; Lin, M.-T. Design of fins with a grooved heat pipe for dissipation of heat from high-powered automotive LED headlights. Energy Convers. Manag. 2019, 180, 550-558. [CrossRef]

28. Liang, F.; Gao, J.; Xu, L. Investigation on a grinding motorized spindle with miniature-revolving-heat-pipes central cooling structure. Int. Commun. Heat Mass Transf. 2020, 112, 104502. [CrossRef]

29. Jeong, M.W.; Jeon, S.W.; Lee, S.H.; Kim, Y. Effective heat dissipation and geometric optimization in an LED module with aluminum nitride (AlN) insulation plate. Appl. Therm. Eng. 2015, 76, 212-219. [CrossRef] 
30. Deng, X.; Luo, Z.; Xia, Z.; Gong, W.; Wang, L. Active-passive combined and closed-loop control for the thermal management of high-power LED based on a dual synthetic jet actuator. Energy Convers. Manag. 2017, 132, 207-212. [CrossRef]

31. Seo, J.-H.; Lee, M.-Y. Illuminance and heat transfer characteristics of high power LED cooling system with heat sink filled with ferrofluid. Appl. Therm. Eng. 2018, 143, 438-449. [CrossRef]

32. Lin, X.; Mo, S.; Jia, L.; Yang, Z.; Chen, Y.; Cheng, Z. Experimental study and Taguchi analysis on LED cooling by thermoelectric cooler integrated with microchannel heat sink. Appl. Energy 2019, 242, 232-238. [CrossRef]

33. Tsai, H.-L.; Le, P.T. Self-sufficient energy recycling of light emitter diode/thermoelectric generator module for its active-cooling application. Energy Convers. Manag. 2016, 118, 170-178. [CrossRef]

34. Sadeghinezhad, E.; Mehrali, M.; Saidur, R.; Mehrali, M.; Latibari, S.T.; Akhiani, A.R.; Metselaar, H.S.C. A comprehensive review on graphene nanofluids: Recent research, development and applications. Energy Convers. Manag. 2016, 111, 466-487. [CrossRef]

35. Joseph, M.; Sajith, V. Graphene enhanced paraffin nanocomposite based hybrid cooling system for thermal management of electronics. Appl. Therm. Eng. 2019, 163, 114342. [CrossRef]

36. Wang, Y.; Al-Saaidi, H.A.I.; Kong, M.; Alvarado, J.L. Thermophysical performance of graphene based aqueous nanofluids. Int. J. Heat Mass Transf. 2018, 119, 408-417. [CrossRef]

37. Taherialekouhi, R.; Rasouli, S.; Khosravi, A. An experimental study on stability and thermal conductivity of water-graphene oxide/aluminum oxide nanoparticles as a cooling hybrid nanofluid. Int. Commun. Heat Mass Transf. 2019, 145, 118751. [CrossRef]

38. Zhao, X.; Jiaqiang, E.; Wu, G.; Deng, Y.; Han, D.; Zhang, B.; Zhang, Z. A review of studies using graphenes in energy conversion, energy storage and heat transfer development. Energy Convers. Manag. 2019, 184, 581-599. [CrossRef]

39. Bahiraei, M.; Heshmatian, S. Graphene family nanofluids: A critical review and future research directions. Energy Convers. Manag. 2019, 196, 1222-1256. [CrossRef]

40. Kazemi, I.; Sefid, M.; Afrand, M. Improving the thermal conductivity of water by adding mono \& hybrid nano-additives con-taining graphene and silica: A comparative experimental study. Int. Commun. Heat Mass Transf. 2020, 116, 104648.

41. Gan, J.S.; Yu, H.; Tan, M.K.; Soh, A.K.; Wu, H.A.; Hung, Y.M. Performance enhancement of graphene-coated micro heat pipes for light-emitting diode cooling. Int. J. Heat Mass Transf. 2020, 154, 119687. [CrossRef]

42. Naghash, A.; Sattari, S.; Rashidi, A. Experimental assessment of convective heat transfer coefficient enhancement of nanofluids prepared from high surface area nanoporous graphene. Int. Commun. Heat Mass Transf. 2016, 78, 127-134. [CrossRef]

43. Akhavan-Zanjani, H.; Saffar-Avval, M.; Mansourkiaei, M.; Sharif, F.; Ahadi, M. Experimental investigation of laminar forced convective heat transfer of Graphene-water nanofluid inside a circular tube. Int. J. Therm. Sci. 2016, 100, 316-323. [CrossRef]

44. Sarafraz, M.; Yang, B.; Pourmehran, O.; Arjomandi, M.; Ghomashchi, R. Fluid and heat transfer characteristics of aqueous graphene nanoplatelet (GNP) nanofluid in a microchannel. Int. Commun. Heat Mass Transf. 2019, 107, 24-33. [CrossRef]

45. Keklikcioglu, O.; Dagdevir, T.; Ozceyhan, V. Heat transfer and pressure drop investigation of graphene nanoplatelet-water and titanium dioxide-water nanofluids in a horizontal tube. Appl. Therm. Eng. 2019, 162, 114256. [CrossRef]

46. Alous, S.; Kayfeci, M.; Uysal, A. Experimental investigations of using MWCNTs and graphene nanoplatelets water-based nanofluids as coolants in PVT systems. Appl. Therm. Eng. 2019, 162, 114265. [CrossRef]

47. Bahiraei, M.; Salmi, H.K.; Safaei, M.R. Effect of employing a new biological nanofluid containing functionalized graphene nanoplatelets on thermal and hydraulic characteristics of a spiral heat exchanger. Energy Convers. Manag. 2019, 180, 72-82. [CrossRef]

48. Purbia, D.; Khandelwal, A.; Kumar, A.; Sharma, A.K. Graphene-water nanofluid in heat exchanger: Mathematical modelling, simulation and economic evaluation. Int. Commun. Heat Mass Transf. 2019, 108, 104327. [CrossRef]

49. Askari, S.; Rashidi, A.; Koolivand, H. Experimental investigation on the thermal performance of ultra-stable kerosene-based MWCNTs and Graphene nanofluids. Int. Commun. Heat Mass Transf. 2019, 108, 104334. [CrossRef]

50. Naddaf, A.; Heris, S.Z. Experimental study on thermal conductivity and electrical conductivity of diesel oil-based nanofluids of graphene nanoplatelets and carbon nanotubes. Int. Commun. Heat Mass Transf. 2018, 95, 116-122. [CrossRef]

51. Alizadeh, J.; Moraveji, M.K. An experimental evaluation on thermophysical properties of functionalized graphene nano-platelets ionanofluids. Int. Commun. Heat Mass Transf. 2018, 98, 31-40. [CrossRef]

52. Girish, T. Some suggestions for photovoltaic power generation using artificial light illumination. Sol. Energy Mater. Sol. Cells 2006, 90, 2569-2571. [CrossRef]

53. Foti, M.; Tringali, C.; Battaglia, A.; Sparta, N.; Lombardo, S.; Gerardi, C. Efficient flexible thin film silicon module on plastics for indoor energy harvesting. Sol. Energy Mater. Sol. Cells 2014, 130, 490-494. [CrossRef]

54. Aoki, Y. Photovoltaic performance of Organic Photovoltaics for indoor energy harvester. Org. Electron. 2017, 48, 194-197. [CrossRef]

55. Apostolou, G.; Reinders, A.; Verwaal, M. Comparison of the indoor performance of 12 commercial PV products by a simple model. Energy Sci. Eng. 2016, 4, 69-85. [CrossRef]

56. Minnaert, B.; Veelaert, P. Efficiency simulations of thin films chalcogenide photovoltaic cells for different indoor lighting con-ditions. Thin Solid Films 2011, 519, 7537-7540. [CrossRef]

57. De Rossi, F.; Pontecorvo, T.; Brown, T.M. Characterization of photovoltaic devices for indoor light harvesting and customization of flexible dye solar cells to deliver superior efficiency under artificial lighting. Appl. Energy 2015, 156, 413-422. [CrossRef]

58. Reynaud, C.A.; Clerc, R.; Lechêne, P.B.; Hébert, M.; Cazier, A.; Arias, A.C. Evaluation of indoor photovoltaic power production under directional and diffuse lighting conditions. Sol. Energy Mater. Sol. Cells 2019, 200, 110010. [CrossRef] 
59. Rühle, S. Tabulated values of the Shockley-Queisser limit for single junction solar cells. Sol. Energy 2016, 130, 139-147. [CrossRef]

60. Jarosz, G.; Marczyński, R.; Signerski, R. Effect of band gap on power conversion efficiency of single-junction semiconductor photovoltaic cells under white light phosphor-based LED illumination. Mater. Sci. Semicond. Process. 2020, 107, 104812. [CrossRef]

61. Yuruker, S.U.; Tamdogan, E.; Arik, M. An Experimental and Computational Study on Efficiency of White LED Packages With a Thermocaloric Approach. IEEE Trans. Components, Packag. Manuf. Technol. 2017, 7, 201-207. [CrossRef]

62. Cohen, A.B.; Kraus, A.D.; Davidson, S.F. Thermal frontiers in the design and packaging of microelectronic equipment. J. Mech. Eng. 1983, 105, 53-59.

63. Chung, Y.-C.; Chung, H.-H.; Lee, Y.-H.; Yang, L.-Q. Heat dissipation and electrical conduction of an LED by using a microfluidic channel with a graphene solution. Appl. Therm. Eng. 2020, 175, 115383. [CrossRef]

64. Holman, J.P. (Ed.) Heat Transfer, 8th ed.; The McGraw-Hill Companies, Inc.: New York, NY, USA, 2000.

65. Principles of Heat and Mass Transfer, 7th ed.; Incropera, F.P.; DeWitt, D.P.; Bergman, T.L.; Lavine, A.S. (Eds.) John Wiley \& Sons, Inc.: New York, NY, USA, 2016. 